\title{
KRAS NM_004985.3:C.39C>A
}

National Cancer Institute

\section{Source}

National Cancer Institute. KRAS NM 004985.3:C.39C>A. NCI Thesaurus. Code C98411.

A nucleotide substitution at position 39 of the coding sequence of the KRAS gene where cytosine has been mutated to adenine. 